\title{
Reflections on African Americans in Baseball: No Longer the Vanguard of Change
}

\author{
Rob Ruck ${ }^{1}$ \\ Accepted: 14 May 2021 / Published online: 8 July 2021 \\ (c) The Author(s) 2021
}

\begin{abstract}
During the last decade, a number of athletes began engaging in social activism. In the aftermath of George Floyd's death, that wave of protest became a tsunami, energizing collegiate and professional athletes and reverberating across society. But baseball, once in the vanguard of sports activism, remained on the sidelines. As the national pastime, it reflected the country's turn toward social Darwinism and segregation at the turn of the 20th century. After World War II, when Jackie Robinson reintegrated the major leagues, it was a catalyst to change off the field. This essay addresses that politicized past and its more quiescent present.
\end{abstract}

Keywords Baseball $\cdot$ Race $\cdot$ Politics

\section{Introduction}

When historians look back at the movement that coalesced in the wake of George Floyd's murder, athletes will rightfully garner accolades for raising public consciousness of racial injustice. Some will trace their advocacy to LeBron James, Dwyane Wade, and their Miami Heat teammates posting a photo of themselves wearing black hoodies after Trayvon Martin was killed in 2012. Others will focus on the Minnesota Lynx players who took to the hardcourt on July 9, 2016 wearing shirts with the message: "Change starts with us. Justice \& accountability," on the front and the names of Alton Sterling and Philando Castile, recently killed by police, on the back along with the now iconic words: Black Lives Matter. They will single out Lynx forward Maya Moore, one of the sport's transcendent talents, who surrendered two seasons in her prime to work to free Jonathan Irons, wrongly convicted for assault and battery. In June 2020, Irons was freed after serving 23 years for a crime he did not commit (Shoichet \& Martin, 2016; Streeter, 2020a, 2020b).

No single athlete will garner more attention than Colin Kaepernick for taking a knee during the playing of the national anthem before NFL games in 2016. For his courage,

Rob Ruck

rucco@pitt.edu

1 University of Pittsburgh, Pittsburgh, PA, USA
Kaepernick became both the most visible and the most abused athlete in the leadup to May 2020. The most visible and the most abused female athlete, Megan Rapinoe, will be remembered, too, not just for leading the USA women's team to victory in the 2019 World Cup, but for kneeling to show her support for Kaepernick and the issues he sacrificed his career to champion. ${ }^{1}$ Not the least of her virtues was how easily she got under Donald Trump's skin. Rapinoe talked the talk, then walked it, emerging as the ultimate winner. Her defiant "I'm not going to the fucking White House" before the team's World Cup triumph echoed the refusal of other squads, like the Golden State Warriors, who wanted nothing to do with a racist xenophobe (North, 2019).

These athletes, in action and by word, called attention to deep-seated problems. That predictably provoked anger and resentment from those in denial about racial realities, unwilling to surrender deeply held prejudices, or eager to channel this dissatisfaction to partisan ends. Some athletes, like Kaepernick, paid a price for their commitments and the protests, after a while, lost momentum. But in the wake of Floyd's extra-judicial public execution on Memorial Day 2020, athletic activists regained their mojo. As public opinion unexpectedly lurched, coaches cowered, institutions issued mea culpas, and the potential for change expanded. By the hundreds, at all levels of sport, athletes spoke out compellingly and articulately. And perhaps more than at any

\footnotetext{
${ }_{1}$ Rapinoe was awarded the Golden Boot and the Golden Ball for being the World Cups' top scorer and best player.
} 
time before, people listened to what they had to say. They forced owners, universities, and corporate sponsors to not only pay attention, but respond to their concerns. Their collective voice mattered because of the role that sport plays in how people think about themselves and society. They resonated because of how much so many of us are invested in sport.

Despite the widely held sentiment that sport should exist in a vacuum, free of politics, it has rarely been that way, especially when it comes to matters of race. Color lines and the quest for a white hope, segregated leagues and conferences, white-only swimming pools, beaches, and parks, and the struggles waged by the black press and activists to demand that sport live up to its rhetoric have roiled the past century. The post-George Floyd moment has called attention to much of that paradoxical past and caused scholars to reassess black athletic activism. ${ }^{2}$

\section{Baseball in America: Black Presence in American Baseball History}

But one sport will hardly be present in the analysis of the role that athletes played in 2020-baseball. Its players and teams were missing from the frontlines. Only a few players and former players spoke out and when they did, the focus was on symbolic issues: eliminating Commissioner Kenesaw Mountain Landis's name from the Most Valuable Player award and changing the Cleveland Indians' name. In Minnesota, the Twins removed a statue of their former owner, Cal Griffith, from outside Target Field after attention was drawn to remarks he made at a Lions Club speech in 1978 explaining that he had decided to relocate from Washington D.C. "when I found out you only had 15,000 Blacks here" (Associated Press, 2020). But it is hard to find a counterpart to Colin Kaepernik, Maya Moore, LeBron James, or Megan Rapinoe in baseball. In 2017, only one player, Oakland A's catcher Bruce Maxwell, took a knee. Maxwell, an African American, said: "I' $m$ kneeling for the people that don't have a voice" (Lee, 2017). But he was a solitary figure and as he told ESPN in July 2020, "I got pushed out of the game because I took a knee during the national anthem" (Schwartz, 2020).

Only when it became clear that athletes in other sports would not 'just shut up and dribble,' did Major League Baseball and a number of former and current Black baseball players begin to assert themselves. MLB, subject to withering criticism as other leagues responded to George Floyd's death and its commissioner's office remained silent,

\footnotetext{
2 This article does not attempt to cover the complex histories of Latinos, Asians, Indigenous people, Hispanic Americans, and Asian Americans in baseball.
}

was the last league to respond. When its 2020 pandemicdelayed season opened in late July, the league permitted players to express their solidarity with the protests when they took to the field, on which the Black Lives Matter's logo was painted. MLB also donated several million dollars to the Players Alliance, a non-profit made up of more than 150 current and former African American players. After the World Series, clubs turned several ballparks into early voting sites for the November election, and when Georgia passed a voting law designed to limit African American voting, the league yanked the 2021 All Star Game from Atlanta (Wagner, 2021).

Unlike MLB, the Players Alliance acted out of conviction and a desire to do the right thing. Its mission is to foster inclusion within baseball and beyond, create more opportunities for African Americans from the dugout to the front office, and combat racial prejudice in sport. While wellorganized and supported by most Black major leaguers, none of its members have the social platform that African American activists in other sports command and their efforts have yet to resonate as deeply.

Given the historic role that baseball played in changing race relations, its absence in the last few years of protest and debate is glaring, but not surprising. After all, African Americans have largely exited the game, currently comprising just 8 percent of major league players. During several World Series in the last decade, hardly a black player could be found on the field. In 2010, perhaps the nadir, there were more African American Republicans elected to the U.S. Congress - two - than played in the World Series that year. The number of black elected officials from the GOP is not likely to climb any time soon; but neither is the number of African American baseball players. That is because baseball matters less to African Americans than at any time since they began playing the game in the late nineteenth century. Ironically, baseball once meant more to African Americans in terms of race than any other sport despite their current detachment from the game. Why was that so? What gave baseball meaning?

For more than a century, baseball mirrored a racial binary, reflecting the rise of Jim Crow after the collapse of Reconstruction, providing cohesion and collective identity during the Great Migration, and becoming a catalyst for the civil rights movement when major league baseball reintegrated after World War II. Shortly before he died in 1968, Martin Luther King, Jr. visited Don Newcombe, a Negro Leaguer who joined Jackie Robinson and Roy Campanella on the Brooklyn Dodgers. "I just want you to know," King said, "and I want the others to know-that without what you did on the baseball field, I would never have succeeded" (Baxter, 
2015). Those feelings were mutual. After King's assassination, black, white, and Latin players refused to play on the day of his funeral, forcing major league baseball to postpone play. ${ }^{3}$

By the twentieth century, baseball had taken on a mythic cast in the United States and parts of the Caribbean. The game's proponents in the States gushed about its progressive, democratizing effects. Walt Whitman compared baseball's importance to the USA Constitution, proclaiming "I see great things in baseball. It's our game-the American game" (quoted in Ward and Burns, 1994, pp. xxvii, e). Not to be outdone, Mark Twain addressed A.G. Spalding and two teams of players at Delmonico's Restaurant in Manhattan in 1889. The ballplayers and Spalding, a former pitcher who owned the Chicago White Sox as well as the most successful sporting goods company in the United States, had just returned from a six-month, 32,000 mile, circumnavigation of the planet. It was a largely fruitless effort to spread the game and expand the market for Spalding's sporting goods to the rest of the world but that hardly constrained Twain. He told the audience, which included future president Theodore Roosevelt, that baseball was "the very symbol, the outward and visible expression of the drive and push and rush and struggle of the raging, tearing, booming nineteenth century." A few years later, National League President and former Pennsylvania governor John Tener declared that the sport was "the very watchword of democracy" (quoted in Seymour, 1989, pp 83, 345).

But baseball in the United States was neither multi-racial nor multi-national and hardly democratic in the early twentieth century. The only venue where those principles were practiced was in Cuba. Baseball by then had surpassed cricket as the most widely played ballgame in the country. Before the Civil War, it was mostly played in New England and the Mid-Atlantic. But soldiers on both sides in the conflict picked up the game during the war and brought it home with them afterwards. As it became the nation's pastime, males and a few females played it from Boston to Honolulu. The overwhelming majority of participants played to play, not for pay. Most teams were organized by boys and men from the same neighborhood, town, or workplace and competed locally. While a few professional leagues had operated

\footnotetext{
$\overline{3}$ Decades later in 2010, Toronto Blue Jays manager Cito Gaston, one of a small number of black managers, said on Jackie Robinson Day that "Without Mr. Robinson, I wouldn't be sitting here and President Obama would not be president of the United States." Quoted in Howie Rumberg, "Now Honoring No. 42 Jackie Robinson Saluted on Anniversary of Breaking MLB's Color Barrier," San Diego UnionTribune, April 15, 2010.
}

since the 1870 s, they were a side show, struggling to commercialize the game. Professional baseball was largely an afterthought.

The sport's significance then had less to do with either its commercial or professional development than the role it played as a vehicle for Americanization on city sandlots. Irish and German immigrants, and then the late nineteenth century wave of 'new immigrants' arriving from Eastern, Central, and Southern Europe, found baseball a way to fit in. Many immigrants who arrived between 1880 and 1920 never learned English or became citizens, nor felt welcome in the United States. Never intending to stay, about 30\% returned home. But the children of those who stayed, speaking one language at home and another at school, wanted to fit in. For many, sport, especially baseball, was a way to gain that acceptance-to become Americans.

But the sport did not offer the same promise to African Americans. The enslaved, including Frederick Douglass, sometimes played baseball when granted a few days from labor after Christmas, but the ability to play was a function of leisure time. Most African Americans, even those who were free, generally lacked that opportunity. A few better off African Americans with more time to devote to sport took up the game in the North after the Civil War. Their teams, often organized by social clubs and fraternal societies, connected black metropolitan elites and demonstrated, as historian Michael Lomax put it, "their capacity for selfdetermination, self-improvement, and freedom" (2003, xix). Though black clubs were shunned by emerging leagues, about fifty African Americans played on mostly white clubs, including several in baseball's top leagues. But few African Americans had the leisure time to practice and develop the muscle memory central to becoming proficient at the game. As a result, they were not as skilled as whites with more time and resources to master the game. ${ }^{4}$

And then, amidst the virulent Social Darwinist backlash of the 1890s, the major leagues expelled their black players, either by passing resolutions to that end or simply getting rid of them without explaining why. Given what African Americans were facing - sharecropping, lynchings, disenfranchisement, scientific racism, the KKK, and Supreme Court sanction of Jim Crow in Plessy v. Ferguson-exclusion from major league baseball was hardly the most grievous blow African Americans absorbed. But it mattered.

Their absence stigmatized African Americans, denying them the chance to participate in a highly visible arena in

\footnotetext{
${ }_{4}$ Those seeking to know more about the Negro Leagues and Caribbean baseball could explore Neil Lanctot, Negro League Baseball: The Rise and Ruin of a Black Institution (University of Pennsylvania Press, Philadelphia: 2004) and Adrian Burgos, Jr., Playing America's Game: Baseball, Latinos, and the Color Line, (University of California Press, Berkeley, 2007).
} 
which Americanism was being defined for European immigrants. The sandlots were becoming Americanization's baptismal fount, a meritocracy where performance mattered more than class or nationality. The sons of immigrants who became major leaguers-John McGraw, Honus Wagner, Joe DiMaggio, Hank Greenberg - were lionized by their nationalities. But blacks were missing from the major leagues and most whites assumed that was because they were not good enough to play top-flight baseball. The absence of African Americans from this exceptionally level playing field was prima facie evidence to many whites that they were not worthy of playing baseball, or for that matter, worthy of citizenship. Few saw their absence as the result of being denied the opportunity to learn the game and compete against whites or as a function of the power relations defining society. Instead, they assumed African Americans were just not good enough to compete.

Major League Baseball not only failed to offer African Americans the means of acculturation it afforded European immigrants, it reinforced prevailing beliefs of African Americans' inherent intellectual and athletic inferiority. Unlike today, the popular wisdom regarding black athletes was that they were naturally inferior. They were thought to be impaired by weak abdominal muscles, lacking in endurance and intellect, and unable to respond under stress. A century later, most people believe the opposite, that African Americans are inherently superior athletes. Wrong then, wrong today.

\section{The Negro Leagues}

The Negro Leagues proved something else. Beyond the boundaries drawn by segregation, black America built a baseball world of its own. Black teams played on city sandlots and country fields, with the best barnstorming their way across the country. Their golden age began on February 13, 1920, when teams from Chicago, Kansas City, and six other cities created the Negro National League (NNL). Jumpstarting three decades of stellar play, Negro League baseball knit together black America after the Great Migration north. It affirmed black competence and grace, forging a collective identity that brought together northern-born blacks and their southern brethren. And though the major leagues were segregated from the 1890s until 1947, these teams showcased interracial play on a level playing field in countless communities, especially on city and milltown sandlots.

Rube Foster, a Texas-born pitcher who ran the Chicago American Giants, convened the meeting at the Paseo YMCA in Kansas City that formed the league. After excelling on the mound, Foster mastered the financial and promotional aspects of the sport. A race man infused with the New Negro consciousness of the times, Foster knew that white teams booked black teams because interracial games drew well at the gate. And in the wake of the Great Migration, as northern black communities exploded in size, he realized that black baseball had the potential to succeed by pitting top black squads against each other. One of the first national black institutions to emerge, the Negro National League flourished. Its players enjoyed higher salaries than most black workers and traveled on Pullman cars, finessing segregation's indignities. Black newspapers trumpeted their exploits, as did some white papers.

The Negro National League's ascent was cut short when Foster was incapacitated from a gas leak at his home. Absent his leadership, it succumbed during the Great Depression, only to be reborn in Pittsburgh in 1933. With Cool Papa Bell flying around the base-paths, Josh Gibson hitting balls further than anyone had seen before, and Satchel Paige loading the bases on purpose, telling his fielders to sit down, and striking out the side, Pittsburgh became the crossroads of a black baseball world stretching into the Caribbean. While black Pittsburgh was not nearly as populous as black Chicago, the city sat along East-West rail lines, making it a stop for black entertainers, leaders, and ballclubs. Its two clubs, the Homestead Grays and Pittsburgh Crawfords, had emerged on local sandlots. The Grays were composed of steelworkers at the legendary Homestead Steel Works on the Monongahela river. The Crawfords were formed by sons of the Great Migration who took their name from the Crawford Bath House, a city recreational center catering to black migrants and European immigrants on the Hill. Both black migrants and European immigrants lived there. The clubs also benefited from numbers bankers, as did black teams in several other cities, as well as talented youth like Josh Gibson. The Grays and the Kansas City Monarchs became the Negro League baseball's longest and most successful organizations. The shorter-lived Crawfords fielded teams in the 1930s with five future Hall of Famers on their 16-man roster that rivaled the heralded 1927 New York Yankees. Together, the Grays and the Crawfords won more a dozen Negro League titles. Seven of the first eleven Negro Leaguers inducted into the Hall of Fame played for one or both of them. Later inductees included Homestead's player/manager/owner Cumberland Posey Jr., the only person in baseball's and basketball's hall of fame.

During these years, baseball became central to black America's story. "The very best," author John Wideman observed, "who not only competed among themselves and put on a good show, but who would go out and compete against their white contemporaries and beat the stuffing out of them... produced in the folk stories that are better than winning in which the exploits get exaggerated and fabled. All that was very important, particularly at a time in America when race relations were at their nadir" (Ruck, 1993).

Black players joined a transnational sporting circuit, with players circulating among the United States, Cuba, Mexico, 
and other Caribbean venues. In the summer, the best Latinos came north to play. Those who were Caucasian or light enough to pass could play in the major leagues; those who were darker-hued joined Negro League teams. In the winter, the best black players headed to the islands or Mexico, playing on multi-racial teams and earning more money and respect than they did in the United States. Newark Eagles shortstop Willie Wells told the Pittsburgh Courier's Wendell Smith that he had returned to Veracruz, Mexico to play in 1944 because "I have a better future in Mexico than in the States. Not only do I get more money playing here, but I live like a king. I am not faced with the racial problem in Mexico.... we are heroes here, not just ballplayers.... I didn't quit Newark and join some other team in the Sates. I quit and left the country. I've found freedom and democracy here, something I never found in the United States" (Smith, 1944).

During World War II, black baseball thrived at the gate, ranking among the top five revenue-producing businesses controlled by African Americans. Despite the pride the Negro Leagues engendered, black sportswriters and activists, both black and white, continued to campaign for major league baseball's integration. Those efforts gained momentum during the war, which encouraged a second, even larger round of the Great Migration and brought millions of African Americans into the armed forces and defense factories. Anti-fascist and pro-democratic rhetoric energized black activism and the contribution African Americans made to the war effort was not lost on all whites. Brooklyn Dodgers president Branch Rickey believed that African American and Latin players could improve his roster and draw fans; the war made it possible for him to act.

\section{Integration in Baseball: The Good and the Bad}

On October 29, 1945, Rickey startled the sporting world when he announced the signing of Jack Roosevelt Robinson to a contract with the Dodgers' top farm club, the Montreal Royals. A tremendous all-around athlete at UCLA, Robinson was best known for his exploits on the gridiron and success in fighting a court martial during the war. Now, after playing a single season with the Kansas City Monarchs, Robinson was catapulted into the limelight. ${ }^{5}$ Progressive voices hailed the signing. "Those who were good enough to fight alongside the whites are plenty good enough to play by the sides of whites," Elmer Ferguson wrote in the Montreal Herald" (quoted in Pittsburgh Courier, November 3, 1945).

\footnotetext{
${ }^{5}$ His brother Mack was a silver medalist at the 1936 Berlin Olympics who returned to their home in Pasadena afterwards and worked as a street sweeper, often wearing his U.S. Olympic team sweatshirt on the job.
}

The Pittsburgh Courier proclaimed that Robinson carried "the hopes, aspirations, and ambitions of thirteen million black Americans heaped on his sturdy shoulders." And when Robinson homered in his second at-bat for the Royals in their season opener in 1946, veteran sportswriter Wendell Smith wrote: "Our hearts beat just a little faster and the thrill ran through us like champagne bubbles" (Smith, 1946). For Joe Bostic, writing in the People's Voice, the game meant that baseball had finally taken up "the cudgel for Democracy" (1945). After a strong season with the Montreal Royals, Robinson debuted in the major leagues on April 15, 1947. The Boston Chronicle's headline trumpeted "Triumph of Whole Race Seen in Jackie's Debut" (quoted in Tygiel, 1997, p. 178). At the end of the season, Robinson won the National League Rookie of the Year award and the Dodgers made it to the World Series. They also set attendance records at home and on the road. As Wendell Smith quipped: “Jackie's nimble, Jackie's quick. Jackie makes the turnstiles click" (Ruck, 2011, p. 93).

For baseball, no moment was more transformative than Jackie Robinson's arrival. Although teams were slow to integrate, more African Americans as well as Latinos began entering the major and minor leagues. They soon reshaped the game. Ballplayers schooled in the Negro Leagues and the Caribbean changed how the game was played, introducing a cohort of men who combined power with speed-a mix which had been missing from the major leagues for decades. Sixty-three African Americans and ten Latinos who had played Negro League baseball eventually entered the majors. Eight of them became Hall of Famers. So would another nine African Americans who did not play Negro League ball but were born before Robinson's breakthrough. Together, they provided the major leagues with their most iconic figures, won far more than their share of individual honors, and were at the core of almost every championship team since 1947, with the exception of the New York Yankees of the 1950s and 60s, for several decades.

The integration of baseball, famously called baseball's great experiment by Jules Tygiel, would have an impact off the field, too, where it changed social attitudes in the runup to Brown v Board of Education, the Montgomery Bus Boycott, and Greensboro sit-ins. Mal Goode, who became the nation's first African American television correspondent in 1962, thought that Robinson's success changed minds. "There must have been thousands of incidents around the country where white businessmen sat and never hired a black to do anything except to mop or to sweep... who said 'What's wrong with it? Let's try it, an experiment.'” Those who witnessed Robinson's fiery play, Goode argued, replicated Rickey's gamble in myriad ways, translating it from the baseball field to the corridors of businesses, banks, and corporations. That, he argued, was what counted the most (Ruck, 2011, pp. 97-100). 
The story of African Americans and Latinos in baseball has long been portrayed as a tale of their shameful segregation and redemptive integration. Segregation was certainly shameful, particularly for a sport so invested in its own rhetoric of democracy and American exceptionalism. But for African Americans and Latinos, integration was also painful. Although long overdue and a catalyst to social change, integration cost black and Caribbean societies control over their own sporting lives. It changed the meaning of sport and not necessarily for the better as it became less about community and more about capital. In the aftermath of Robinson reaching the majors, integration destroyed the Negro Leagues-taking its young stars-Willie Mays, Roy Campanella, Henry Aaron, Roy Campanella, and Ernie Banksand its fans, while television and suburbanization laid waste to sandlot clubs in black and white neighborhoods. As Hall of Famer Buck Leonard wryly noted, "After Jackie, we couldn't draw flies" (Leonard, 1993). Black owners, GMs, and managers soon disappeared, and more players lost jobs in black baseball than gained spots in the majors. This outcome was not predestined. If integration had occurred in more optimal ways, African Americans might have retained a degree of power over the sport. But Major League Baseball (MLB) never considered incorporating black teams, owners, or managers, and ignored Negro League owners' request to become a high minor league. Like black papers, colleges, and businesses, the Negro Leagues paid a price for integration-extinction.

"I think a lot was lost when the Negro Leagues went belly-up," John Wideman concluded. "After all, this is supposed to be a culture... of diversity and losing institutions that have that long a life and play that crucial a role in the community [is] very worrisome.... Integration has become a very bald choice for black people. Do it our way. Come on board. And we have forgotten that James Baldwin... posed the question: Should we integrate into a burning house?" (Ruck, 1993). August Wilson's Pulitzer Prize winning play Fences is about a Negro Leaguer who becomes a garbageman on Pittsburgh's Hill. "If you are all together standing outside the doors of white American society and you cannot participate in this society, then there is a certain strengthening in who you are as a people," Wilson stressed. "Baseball gave you a sense of belonging." At those games, Wilson said, "The umpire ain't white. It's a black umpire. The owner ain't white. Nobody's white. This is our thing, and I think it's important to transfer that over into the community-and we have our everything - until integration, and then we don't have our nothing" (Ruck, 2011, p 47) (Ruck, 1993).

Mal Goode, who grew up across the street from the men who founded the Homestead Grays and developed close relationships with black ballplayers, was more circumspect. "Integration had its disadvantages from the standpoint of baseball and black owners knew that," he said. "But the broad-minded said it's going to come eventually anyhow." Black owners thought that the major leagues would incorporate them into their operations. "That was a wild dream," Goode reflected, "but they saw, which is the greater, shall we do it, shall we accept it, or shall we continue with segregated baseball." As with the integration of the schools and businesses, there were losses as well as gains. "But what we gained is the greater," Goode affirmed, "We got our selfrespect back and you had to be black to understand what that meant" (Goode, 1991).

But when Jackie Robinson hurdled baseball's racial divide, the Negro Leagues were sacrificed on integration's altar. Integration was a resounding success on the field, at the box office, and in changing racial attitudes, but black America lost control over its sporting life. The players who came of age in the Negro Leagues constituted the greatest burst of talent yet to hit the big leagues, but when they retired, the number of black players plummeted, and baseball lost its grip on black America (Ruck, 1986) (Lanctot, 2008) (Burgos, 2007).

The disintegration of the Negro Leagues as well as the decline of community-based independent sport during the 1950s had damaged the black-controlled infrastructure of sport that had formed during segregation. While the first wave of African Americans in the major leagues had learned the game from black coaches and managers, the second wave was forced to develop in MLB's minor leagues. These ballplayers did so without the benefit of African American coaches and on teams based in the South where they encountered racial hostility on and off the field. Their journey to the majors was not for the faint of heart.

The African Americans and Latinos who overcame these obstacles often excelled. Their numbers climbed steadily and African Americans alone filled more than a quarter of roster spots in the late 1970s. At the 1975 All Star game, African Americans comprised about forty percent of all non-pitching selections. When fans debated who the game's greatest players in the 1960s and 70s were, Willie Mays, Henry Aaron, Roberto Clemente, and other African Americans were at the top of their lists. But at the same time, African Americans held few managerial or front office positions.

Dodgers General Manager Al Campanis changed that. He drew attention to the lack of power African Americans held off the field when he appeared on Nightline in 1987 to mark the 40th anniversary of Jackie Robinson's debut. A last-minute substitution for Don Newcombe, Campanis had not prepared for the interview, which took place after a long workday. In his office at Dodger Stadium, Campanis had three photos on the wall, of Roberto Clemente, Sandy Koufax, and Jackie Robinson. He had signed Clemente, a darkskinned Puerto Rican, and Koufax, a Jew, and stuck up for Robinson when they were teammates on the Montreal Royals during his first season. Knowing that Branch Rickey did 
not want Robinson to fight back when attacked, Campanis offered to do it for him. After the season, Robinson invited him to be one of two white ballplayers on a barnstorming tour. But when Nightline moderator Ted Koppel asked Campanis about the dearth of black owners, general managers, and managers in major league baseball, his cringeworthy answers came across as defensive and to many, racist. He implied that there were race-based differences in intellect and aptitude that prevented African Americans from attaining these positions. The more he tried to extricate himself from these remarks, the worse it became for him.

Campanis lost his job over the interview, but as New York Yankee Reggie Jackson wrote, "it was the best thing to happen to minorities in baseball since Jackie Robinson" (Jackson, 1987). Embarrassed by the fallout, major league teams subsequently hired record numbers of minorities and women to front office and coaching staffs. They did a better job diversifying the front office than they did in continuing to field black players. The number of African Americans playing professional baseball had already begun to plummet by 1987. Many major leaguers with a degree of African heritage were from the Caribbean basin, which was sending more of its native sons to the majors every season. By 2007, about 8 percent of major leaguers were African Americans, down seventy percent from 1975. It remained at about that level ever since. ${ }^{6}$

\section{Decline of Baseball Interest in the Black Community}

There are multiple reasons for this decline, beginning with integration's dire impact on the Negro Leagues, where black talent had incubated during segregation. The Negro National League folded after the 1948 season, the Negro American League lingered a bit longer before succumbing (Ruck, 2011). Meanwhile, corporate forces, particularly television, revamped sport and independent sandlot clubs all but vanished. As these two black-controlled tributaries - the Negro Leagues and sandlots in African American neighborhoodsdried up, the number of African Americans playing baseball began to fall. By then, colleges and universities were offering scholarships for football and basketball to talented black youth; those scholarships were more valuable than the small signing bonuses and the vagaries of minor league baseball. By the 1970s, football and basketball had far more cachet than baseball, especially in black communities.

Overall, youth baseball became more of a suburban game played disproportionately by boys in economically secure households in white communities. Much of this

\footnotetext{
${ }^{6}$ A later study concludes that the number of African American players was lower, 17.7 percent of all major leaguers in 1987, while another $12.3 \%$ were from Latin America.
}

demographic shift had to do with how boys learned the game, which requires instruction and frequent opportunities to play. The decline of sandlot ball in black communities where the game had long been popular meant that there were far fewer men passing on their passion for the game and teaching boys baseball's intricacies. Nor were there accessible, affordable alternatives. Youth seeking to reach a higher level of play instead gravitated to traveling teams and sought individualized training, options that many black youth found too costly to pursue. High schools, meanwhile, feature football and basketball (which also benefits from AAU and shoe company-financed tournaments) but tend to downplay baseball. The major league baseball draft also evolved, with a greater number of players drafted from NCAA programs than from high schools. But playing college baseball was less attractive financially than playing football and basketball because unlike those sports, athletic scholarships for baseball are not full grants in aid. Finally, MLB turned to the Caribbean basin as a cost-effective source of new players. Clubs often signed scores of the young Latinos for trifling bonuses, discarding all but the few who demonstrated the most promise. Beginning in the 1990s, MLB began industrializing the development of youth in the Caribbean, signing boys the year they turn 17 and training them year-round in academies in the Dominican Republic. Most of the boys signed never leave the island but those who do are often among the best players in the game. Signing Latin players also slashed player development costs, something the bottom-line oriented industry has long sought to do. Dominican Republic alone sends more players to the major and minor leagues than the entire African American population while overall, Latinos make up almost thirty percent of the major leagues and a greater percentage of minor leaguers (Ruck, 2011, chap. 8 and 9).

By the twentieth century, baseball's allure had dissipated for black youth and the game had become unhinged from daily life in the community. Despite what baseball once meant to black America, it matters less to African Americans than it ever did. And African Americans matter less in baseball than at any time since 1947. So what? African Americans hardly lack sporting opportunities. If anything, sport holds too much sway among black youth and diverts attention from academic and vocational alternatives. Nor does the black community need baseball anymore to gain the cohesion and collective self-esteem that the Negro Leagues offered it during segregation or the energy that Robinson's triumph generated. It suffers little from a low profile in the game. Hispanic Americans and Latinos are much more invested in baseball than African Americans. Because they have encountered not only racial but cultural hostility, they were frequently more outspoken. Felipe Alou wrote a cover story for Sport magazine in 1963 that stated: "Latin-American ballplayers Need a Bill of Rights," which led to the 
Giants trading him. Roberto Clemente defied cultural and racial animus on and off the field his entire career. (Alou and Hano 1963).

Major League Baseball has more at stake, especially its image as a democratic and inclusive sport. Its capacity to peddle nostalgia has helped it overcome enormous competitive imbalances among big and small markets and a head-inthe-sand approach to performance enhancing drugs. Baseball regularly salutes the Negro Leagues as a marketing ploy and hails Robinson as its greatest hero. Unlike the 1940s, when many owners feared that Robinson would attract black fans and scare away white ones, they are now eager to develop more black stars and attract more black patrons. Owners worry about their fan base, which is aging relative to other widely played team sports.

"All cultures bring something different to the game," Mets outfielder Gary Matthews Jr. said in 2010 as baseball celebrated Jackie Robinson Day. "The African American player, there is a charisma that he brings from his culture... a little spice.... That little spice is missing when we're not participating." Matthews, the lone African American on the Mets that day, was released later that summer (Waldstein, 2010). MLB, sensitive to its image, has invested in communitybased baseball programs in African American communities for more than a decade through RBI (Reviving Baseball in Inner Cities). Their commitment is a public relations gesture but one that also seeks to produce more black players. An array of grassroots sport for development programs have also formed leagues for youth and used baseball to encourage their intellectual and social development as well as aptitude for the game. But baseball will not regain the sway it once had over African Americans.

The African American athletes who have transcended sport since the late 1960s have not been baseball players. Perhaps none was of these paladins was more significant than Muhammad Ali, who went from the most reviled black man in the country to the winner of the Presidential Medal of Freedom and the athlete chosen to light the Olympic Torch at the Atlanta Games in 1996. Women and men who ran track, played football and basketball, and competed in gymnastics and other sports have been in sport's vanguard for change, but baseball has not produced comparable figures.

\section{Reflections and Recommendations}

I have come to think of sport at its best as a republic of play, offering a vision of society that's ethical and transparent, an arena where fairness and performance matter the most, people validate their worth by the strength of their opponents, prize sportsmanship, and celebrate the body, mind, and being on a team. That is why sport matters so much beyond its commercial heft; it models the promise of the United States that has yet to be fully achieved. And it has long played a role in the ongoing quest for racial equality.

Sport in the republic of play creates social capital because being a part of a team in which you have each other's back and compete with a common purpose is one of life's treasures. And in this still to be realized democratic republic, legitimacy —on and off the field—is derived from the will of the people. As the eminent historian Marcus Rediker, puts it, the republic, in its "radical democratic form is a bottomup vision of the American Revolution and its legacy, one designed to include workers, women, and freed people in the American polity. 'The people,' in all their many forms and contradictions, are the sovereign power" (Rediker, 2017).

In such a society, equal access to free time and sport are fundamental rights and the health and well-being of citizens are paramount. But just as the early American republic paradoxically embraced slavery and exclusion alongside national liberation and notions of freedom, the republic of play can be a mean and vicious place-where youth become vulnerable commodities on a global supply chain; the athletes we applaud suffer physical, neurological, and psychological trauma; and sport used to promote anger and misogyny, bringing out the worst-not the best-in us. Too many youth are denied access to sport's prerequisites, including health care and nutrition, and cannot afford to partake of sport.

Sport's downside is as undeniable as its upside. Consider the number of African American youth for whom sport has not only been a dead end but foreclosed other alternatives. Think of the black athletes whose bodies and minds were damaged or destroyed as they became programming for the sports-entertainment complex. Dwell (but not for too long) on opportunists like Donald Trump who barely attempted to conceal racist fearmongering and motivated their base by accusing Colin Kaepernick and others of defiling the flag.

Sport and the African American community no longer need a Rube Foster, Jackie Robinson, or Muhammad Ali to champion racial equality and progress. But we will need many Maya Moores, Meghan Rapinoes, and Colin Kaepernicks to prevent the nation from lapsing back into a passive acceptance of racism and inequality. What form might their commitments take in coming years? The coronavirus pandemic made it impossible to ignore the fundamental disparities in health and fitness that resulted in African Americans suffering disproportionately. Symbolic change will not make those inequalities go away. And while many would revel in the glory of Colin Kaepernick being given a chance to return to play and lead a team to the Super Bowl, it would be of greater importance to advance a larger health, fitness, and sport agenda for disadvantaged communities. While African Americans are overrepresented among the very best of elite athletes, they also endure the worst overall public health demographics. Far too many black youth do not even have the chance to play any sport. 
Individual black athletes, including those ballplayers whose salaries have soared into the sporting stratosphere, could donate their entire paychecks to improving public health conditions without having a perceptible impact. But they could emulate Johan Koss and Tegla Laroupe. Koss, after winning three gold medals in speed skating at the 1994 Lillehammer Olympic Games, created Right to Play, a catalyst for sport for development projects. Laroupe, the four foot, eleven inch, tall, $82 \mathrm{lb}$, Kenyan, was one of the greatest distance runners in history. Returning to her village after winning the 1994 New York City Marathon, women told her: "You showed that we are like the men-we can do things. We are not useless." Her Tegla Laroupe Peace Foundation has mediated conflicts in Africa and championed immigrants forced to flee their countries because of war, climate change, and poverty. Koss and Laroupe offer models for sustained athletic activism that endure longer than social media (Johansen) (Price, 2016).

Major league baseball, which has never been stronger as a business but weaker as a game, could also make significant, ongoing commitments that would change people's lives for the better. It could use its network of major and minor league teams to invest in public health and encourage systemic change in diet, medical care, and youth fitness. It could give local activists a platform and learn from them what needs to be done. That would matter much more than nudging the percentage of black baseball players higher. And MLB, like other leagues and corporate players in sport, does respond to sustained public pressure.

Although this nation is at a crossroads, with white supremacists emboldened by a now defeated president who still counts on their support, we will never return to segregated sport. It is far more likely that African Americans will gain more power over sporting institutions in coming years. Sport will remain a vehicle for building social capital and baseball will be part of that process, even if other sports play more compelling roles. But as Commissioner Bart Giamatti said in 1988, when the Pittsburgh Pirates became the first team to honor black baseball's legacy, "We must never lose sight of our history, insofar as it is ugly, never to repeat it, and insofar as it is glorious, to cherish it." Baseball's role in African American history should not be forgotten and it is worth cherishing (Levin, 1988).

Open Access This article is licensed under a Creative Commons Attribution 4.0 International License, which permits use, sharing, adaptation, distribution and reproduction in any medium or format, as long as you give appropriate credit to the original author(s) and the source, provide a link to the Creative Commons licence, and indicate if changes were made. The images or other third party material in this article are included in the article's Creative Commons licence, unless indicated otherwise in a credit line to the material. If material is not included in the article's Creative Commons licence and your intended use is not permitted by statutory regulation or exceeds the permitted use, you will need to obtain permission directly from the copyright holder. To view a copy of this licence, visit http://creativecommons.org/licenses/by/4.0/.

\section{References}

Alou, F., \& Hano, A. (1963). Latin-American ballplayers Need a Bill of Rights. Sport.McFarland and Company Inc.

Armour, M. and Levitt, D. Baseball Demographics, 19472016 , https://sabr.org/bioproj/topic/baseball-demographi cs-1947-2016/

Associated Press. (2020, June 19). Twins remove statue of former owner Calvin Griffith over racist comments. Portland Press Herald. https://www.pressherald.com/2020/06/19/twins-removestatue-of-former-owner-calvin-griffith-over-racist-comments/.

Baxter, K. (2015, March 16). Dodgers, forever linked to civil rights movement, to host special game. Los Angeles Times. https:// www.latimes.com/sports/dodgers/la-sp-civil-rights-jackie-robin son-20150316-story.html

Burgos, A. (2007). Playing America's game: Baseball, Latinos, and the color line. University of California Press.

Goode, M. (1991, February 23). Interview with Rob Ruck. Pittsburgh, PA.

Jackson, R. (1987, May 11). We have a serious problem that isn't going away. Sports Illustrated, 66, 40-48.

Johansen, R. (n.d.). Playing fair on and off the sports fields. United Nations Office on Drugs and Crime. http://www.unodc.org/newsl etter/200602/page007.html

Lanctot, N. (2008). Negro league baseball: the rise and ruin of a Black institution. University of Pennsylvania Press.

Lee, J. (2017, September 24). A's Maxwell kneels during anthem. MLB. com. https://www.mlb.com/news/a-s-bruce-maxwell-kneels-foranthem-c255796662

Leonard, B. (1993). personal.

Levin, D. P. (1988). Pittsburgh recalls a neglected title. New York Times.

Lomax, M. E. (2003). Black baseball entrepreneurs, 1860-1901: operating by any means necessary. Syracuse University Press.

North, A. (2019). Why the president is feuding with Megan Rapinoe, star of the US women's soccer team. Vox. https:// www.vox.com/identities/2019/7/3/20680073/megan-rapin oe-trump-world-cup-soccer

Players Alliance, https://theplayersalliance.com/media/

Price, S. L. (2016). Olympics about more than winning for Refugee team. Sports Illustrated. https://www.si.com/olympics/2016/07/ 24/olympics-rio-2016-refugee-team

Rediker, M. (2017, May 3). Email correspondence.

Ruck, R. (1986). Sandlot seasons: Sport in Black Pittsburgh. University of Illinois Press.

Ruck, R. (1993). Kings on the hill: Baseball's forgotten men. PBS.

Ruck, R. (2011). Raceball: How the major leagues colonized the black and Latin game. Beacon Press.

Rumberg, H. (2010, April 15). Now honoring No. 42: Jackie Robinson Day in majors. San Diego Union Tribune. https://www.sandiegoun iontribune.com/sdut-now-honoring-no-42-jackie-robinson-day-inmajors-2010apr15-story.html

Schwartz, J. (2020, July 9). Ex-Athletics catcher Bruce Maxwell: I was pushed out of MLB for kneeling. New York Post. https://nypost. com/2020/07/08/bruce-maxwell-i-was-pushed-out-of-mlb-forkneeling/

Seymour, H. (1989). Baseball: The early years. Oxford University Press.

Shoichet, C. E., \& Martin, J. (2016, July 12). Off-duty cops walk out over WNBA players' Black Lives Matter shirts. CNN. https:// 
www.cnn.com/2016/07/12/us/wnba-minnesota-lynx-black-livesmatter-shirts/index.html

Smith, W. (1944). Introducing El Diablo wells of Mexico. Pittsburgh Courier.

Smith, W. (1946). The sport's beat (p. 12). Pittsburgh Courier.

Streeter, K. (2020). As athletes pursue justice women are a force without fanfare (p. 1). New York Times.

Streeter, K. (2020, March 9). W.N.B.A. Star Maya Moore Helped Overturn His Conviction. 'She Saved My Life.'” . New York Times. https://www.nytimes.com/2020/03/09/sports/basketball/mayamoore-jonathan-irons.html? searchResultPosition $=4$

Tygiel, J. (1997). Baseball's great experiment: Jackie Robinson and his legacy. Oxford University Press.
Waldstein, D. (2010). On Robinson's Day, a met reflects. New York Times.

Wagner, J. (2021). Activism was unusual for baseball, but not for sports. New York Times.

Ward, G. C., \& Burns, K. (1994). Baseball: An illustrated history. A.A. Knopf.

Publisher's Note Springer Nature remains neutral with regard to jurisdictional claims in published maps and institutional affiliations. 